\title{
PRODUCTION OF BIOBACTERICIDES FOR CRUCIFERS BLACK ROT CONTROL: EFFECT OF NITROGEN SOURCES
}

\author{
Ida E. Zahović*, Zorana Z. Rončević, Jovana J. Đuran, Ivana Ž. Mitrović, \\ Jovana A. Grahovac, Jelena M. Dodić
}

University of Novi Sad, Faculty of Technology Novi Sad, Department of Biotechnology and Pharmaceutical Engineering, Novi Sad 21000, Bulevar cara Lazara 1, Serbia

\author{
${ }^{*}$ Corresponding author: Ida Zahović \\ Phone: +381655661243 \\ Fax: +38121450413 \\ E-mail address: ida.zahovic@tf.uns.ac.rs
}

\begin{abstract}
The aim of this study was to examine the effects of variation of organic (yeast extract, soybean flour and peptone) and inorganic nitrogen sources $\left(\mathrm{NaNO}_{2}, \mathrm{KNO}_{3}\right.$ and $\left.\left(\mathrm{NH}_{4}\right)_{2} \mathrm{HPO}_{4}\right)$ in medium for biobactericides production by Bacillus subtilis ATCC 6633 . The antibacterial activity of samples against the reference strain Xanthomonas campestris ATCC 13951 and different Xanthomonas strains isolated from cabbage, kale and cauliflower was determined in vitro by discdiffusion method. Following statistical analysis, it was concluded that both nitrogen sources have statistically significant effect on biobactericides production under applied conditions whereby the influence of inorganic nitrogen is more pronounced. The results of Duncan's test suggested that the highest biosynthesis of antibacterial compounds was achieved in both media, with or without yeast extract, when $\mathrm{NaNO}_{2}$ was used as an inorganic nitrogen source. The results from this study can be used in further research to improve biobactericides production by the reference $B$. subtilis strain.
\end{abstract}

Keywords: biobactericide production, Bacillus subtilis, nitrogen source, Black rot, Xanthomonas campestris

\section{INTRODUCTION}

Plant diseases caused by phytopathogenic bacteria and fungi present a major problem nowadays for many crops cultivation worldwide. In recent years, the interest in biological control of plant pathogens has significantly increased, due to the need for finding alternative solutions to replace the usage of physical and chemical seed treatments that have showed only limited success (Taylor et al., 2002; Fira et al., 2018).On the other hand, usage of natural products obtained from plants has been widely disseminated because its chemical composition and biological activities may vary depending on the geographical region, collecting time and plant source (Meneses et al., 2009). Taking into account all mentioned before, application of antagonistic microorganisms that produce inhibitory substances for plant pathogens has shown to be one of the most promising solutions (Radovanović et al., 2018).

Biocontrol agents of microbial origin that show antagonistic capacity could be classified into both fungal and bacterial groups (Suárez-Esstrella et al., 2013). Due to their ability to synthesize more than 5000 different bioactive compounds, microorganisms of genera Bacillus, Penicillium, Streptomyces, Cephalosporium and Micromonospora are the most significant (Khan et al., 2011). Members of the Bacillus genera are mostly used in biological control because of their diverse secondary 
metabolism and the ability to produce a wide variety of structurally different antagonistic substances (Fira et al., 2018). The genus Bacillus represents a large group of Gram-positive bacteria that comprises 377 species (Caulier et al., 2019) which produce biofungicides, enzymes that degrade fungal structural polymers and antifungal volatiles (Leelasuphakul et al., 2008; Radovanović et al., 2018). Among the Bacillus genus, Bacillus subtilis is highly promising producer of more than 70 different metabolites with antimicrobial activity (Fernandes et al., 2007). Strains of $B$. subtilis have approximately $4-5 \%$ of its entire genome devoted solely to synthesis of secondary metabolites, with the capability to produce more than two dozen structurally diverse antimicrobial compounds (Wise et al., 2012; Fira et al., 2018). GRAS (Generally Regarded As Safe) status qualifies $B$. subtilis as an excellent candidate for the usage in biocontrol of plant pathogens (Leelasuphakul et al., 2008).

Lately, the use of Bacillus spp. is studied for control of the one of the most important plant disease known as black rot, which is caused by the bacterium Xanthomonas (Luna et al., 2002). Xanthomonas species and pathovars are classified taxonomically on the basis of their ability to discriminate between different host plants (Vorhölter et al., 2003). Among the others, the most notable of these pathogens are Xanthomonas campestris pv. campestris, the causal agent of black rot of crucifers, $X$. euvesicatoria, $X$. perforans, $X$. vesicatoria and $X$. gardneri, the causal agents of bacterial spot of pepper and tomato, and $X$. campestris pv. malvacearum, which causes angular leaf spot of cotton (ElHendawy et al., 2005; Mansfield et al., 2012; Larrea-Sarmiento et al., 2018; Rončević et al., 2019). Results from several studies indicated that Bacillus spieces produced antibacterial compounds effective against $X$. campestris strains (Salerno and Sagardoy, 2003; Monteiro et al., 2005; Issazadeh et al., 2012; Rončević et al., 2014).

The production of antimicrobial compounds by microbial cells is strongly influenced by the composition of medium
(Peighamy-Ashnaei et al., 2007; Tabbene et al., 2019). It is of great importance to formulate the medium composition so that it favours biosynthesis of antimicrobial metabolites. The proper selection of carbon, nitrogen and phosphorus sources, as the most important nutrients in the cultivation medium, and precisely definition of their concentrations are essential to increase the yield of desired metabolite (Grahovac et al., 2014). According to literature data, the type of nitrogen source as a growth-limiting nutrient is extremely important in the optimization of the production of many secondary metabolites (Davis et al., 1999).

In order to ensure maximal biosynthesis of desired antimicrobial compounds it is necessary to identify the best medium composition and process conditions for cultivation of selected producing strain. The aims of this study were the evaluation of antibacterial metabolites biosynthesis by B. subtilis ATCC 6633 and optimization of glycerol-based medium composition, in terms of nitrogen sources type. Test microorganism used for the optimization of cultivation medium composition was the reference strain $X$. campestris ATCC 13951 , the causative agent of black rot, a disease that causes serious damage to plants from Brassicaceae family (Da Silva et al., 2019). Further evaluation of antibacterial metabolites biosynthesis by $B$. subtilis ATCC 6633 on optimal cultivation medium was tested on Xanthomonas strains isolated from cabbage, kale and cauliflower.

\section{MATERIALS AND METHODS}

\section{Microorganisms}

The reference strain Bacillus subtilis ATCC 6633 was used in these experiments as producing microorganism. Reference strain Xanthomonas campestris ATCC 13951 and three different Xanthomonas strains isolated from cabbage, kale and cauliflower were used as test microorganism for in vitro determination of antibacterial activity. The pure cultures of both microorganisms were stored on agar slants at $4{ }^{\circ} \mathrm{C}$ and subcultured every four weeks. 


\section{Cultivation media}

The commercial semi-synthetic medium, Nutrient Agar (HiMedia ${ }^{\circledR}$, India), was used as storage and refreshments medium for producing microorganism. The inoculum was prepared by cultivation of applied bacterial strain on Nutrient Broth (HiMedia ${ }^{\circledR}$, India).

Biosynthesis of antibacterial metabolites was performed on Nutrient Broth as well as on media formulated in accordance with previous research (Rončević et al., 2014) and the selected experimental design. In these media different type of organic (yeast extract, soybean flour and peptone $(0.5 \mathrm{~g} / \mathrm{L}))$ and inorganic nitrogen sources $\left(\mathrm{NaNO}_{2}, \mathrm{KNO}_{3}\right.$ and $\left(\mathrm{NH}_{4}\right)_{2} \mathrm{HPO}_{4}$ $(1.0 \mathrm{~g} / \mathrm{L}))$ were varied. Media also contained glycerol $(20.0 \mathrm{~g} / \mathrm{L}), \mathrm{K}_{2} \mathrm{HPO}_{4}(5 \mathrm{~g} / \mathrm{L})$, $\mathrm{CaCO}_{3}(1.7 \mathrm{~g} / \mathrm{L}), \mathrm{MgSO}_{4} \times 7 \mathrm{H}_{2} \mathrm{O}(0.5 \mathrm{~g} / \mathrm{L})$ and $\mathrm{MnSO}_{4} \times 4 \mathrm{H}_{2} \mathrm{O}(0.05 \mathrm{~g} / \mathrm{L})$. The $\mathrm{pH}$ value of all media was adjusted to $7.0 \pm 0.2$ prior to sterilization by autoclaving at 121 ${ }^{\circ} \mathrm{C}$ and 2.1 bar for $20 \mathrm{~min}$. The medium used for storage and incubation of test microorganism was YMA (HiMedia ${ }^{\circledR}$, India).

\section{Inoculum preparation}

The inoculum was prepared on the mentioned media in two steps. Firstly, the producing culture was refreshed by stationary incubation at $28{ }^{\circ} \mathrm{C}$ for $48 \mathrm{~h}$. The second step involved the cells multiplication by double passaging procedure. A loop of producing microorganism cells was transferred from a freshly prepared agar slant into the liquid medium.

The second passage was inoculated with $10 \%(\mathrm{v} / \mathrm{v})$ of broth obtained in the first. The incubation of each passage was carried out under aerobic conditions at $28{ }^{\circ} \mathrm{C}$ and $150 \mathrm{rpm}$ (laboratory shaker KS 4000i control, Ika ${ }^{\circledR}$ Werke, Germany) for 24 h. The prepared inoculum was used for inoculation of all investigated media.

\section{Biosynthesis conditions}

Production of antimicrobial metabolites was carried out in $300 \mathrm{~mL}$ Erlenmeyer flasks containing $100 \mathrm{~mL}$ of cultivation media of the appropriate composition. Inoculation was performed in sterile conditions by adding $10 \%(\mathrm{v} / \mathrm{v})$ of inoculum prepared as previously described. The biosynthesis of compounds with antibacterial activity was carried out under aerobic conditions at $28^{\circ} \mathrm{C}$ and $150 \mathrm{rpm}$ (laboratory shaker KS 4000i control, Ika ${ }^{\circledR}$ Werke, Germany) for $96 \mathrm{~h}$.

\section{In vitroantibacterial activity assay}

Antibacterial activity of the obtained cultivationbroths, cell-free cultivation broths and thermally treated cell-free cultivation broths was determined in vitro, by standard disc-diffusion method (Bauer et al., 1966). The preparation of cell-free samples included the centrifugation at 10000 rpm (Rotina 380 R, Hettich Lab Technology, Germany) for 15 min and filtration through a $0.22 \mu \mathrm{m}$ nylon membrane filter (Agilent Technologies Inc., Germany).

Thermally treated cell-free samples were also centrifuged and filtered through a $0.22 \mu \mathrm{m}$ nylon membrane filter and then thermally treated at $100^{\circ} \mathrm{C}$ for $10 \mathrm{~min}$. All samples were concentrated by evaporation on a rotary vacuum evaporator (Ika ${ }^{\circledR}$ Werke, Germany) to one tenth of the initial mass.

The test microorganism was grown on YMA (HiMedia ${ }^{\circledR}$, India). Agar was melted, cooled to $50 \pm 1{ }^{\circ} \mathrm{C}$, and mixed in sterile conditions with the prepared suspension of test microorganism in a ratio of 9:1. Sterile $5 \mathrm{~mm}$ disks (HiMedia ${ }^{\circledR}$, India) were placed on the inoculated agar plates and impregnated with $10 \mu \mathrm{L}$ of the concentrated samples. After the incubation of test plates at $25^{\circ} \mathrm{C}$ for $72 \mathrm{~h}$, the inhibition zone diameters were measured and expressed in millimeters $(\mathrm{mm})$.

\section{Experimental design and data analysis}

All experiments were carried out in triplicate and the results were averaged. The obtained data were processed using analysis of variance (One-Way ANOVA and Two-Way ANOVA). Significant differences between the means were determined by Duncan's multiple range test at the significance level of $\alpha=0.05$ using Statistica 13.2 software (Dell Inc., USA).

\section{RESULTS AND DISCUSSION}

In accordance with the aim of this research, the production of antibacterial 
compounds effective against Xanthomonas campestris by Bacillus subtillis ATCC 6633 was performed on cultivation media with different organic and inorganic nitrogen sources. All tests were performed on a reference strain $X$. campestris ATCC 13951 and validation of results and its efficacy was tested on Xanthomonas strains isolated from cabbage, kale and cauliflower. At the end of the bioprocess, different samples of cultivation media were prepared and analysed.

Thermally treated cell-free cultivation broth samples were not effective against the applied test microorganism (no inhibition zones was formed). Therefore, data for cultivation broth and cell-free cultivation broth samples were further observed.

\section{Effect of different sample preparation method on the antibacterial activity}

In order to examine the effect of sample preparation method on the antibacterial activity, statistical analysis of inhibition zone diameters against $X$. campestris ATCC 13951 was carried out. The results of one-way ANOVA analysis are given in Table 1.

According to the results presented in Table 1 , the sample preparation method was found to be statistically significant $(p<0.05)$ at the $95 \%$ confidence level. The obtained results suggest that procedures applied for sample preparation have statistically significant effect on the formation of inhibition zones against $X$. campestris ATCC 13951, which is confirmed by F-value of 75.952 . The results of the statistical analysis are also presented graphically in Figure 1.

Figure 1 shows the results of statistical analysis on the effect of different sample preparation method on their antibacterial activity. Considering the mean values of inhibition zone diameter for both samples groups, it can be noted that the live bacterial cells in cultivation broth proved to be more effective against $X$. campestris ATCC 13951 under the applied experimental conditions compared to cellfree broth. This is probably due to biocontrol mechanism. According to literature data antibiosis is the major mechanism of Bacillus sp. responsible for the disease control (de Paula Kuyat Mates et al., 2019). The highest inhibition zone diameter formed by cultivation broth was $26.00 \mathrm{~mm}$. This value was much greater than values of inhibition zone diameter from literature data obtained by methanol and aqueous extract of several plants (De Britto et al., 2011). On the other side, maximal inhibition zone diameter for cellfree cultivation broth was $20.00 \mathrm{~mm}$. The obtained results suggested that cells of $B$. subtilis ATCC 6633 also have antibacterial activity against the tested phytopathogenic bacteria.

This result is in accordance with statement from literature that $B$. subtilis strains can be considered as potentially antagonistic agent for biological control of bacterial plant diseases (Salerno and Sagardoy, 2003) and that the antibiotic activity is associated with the cells (Huang and Chang, 1975).

\section{Effect of different nitrogen sources on the antibacterial compounds produc- tion}

In order to evaluate the production of antibacterial compounds effective against $X$. campestris ATCC 13951 by $B$. subtilis ATCC 6633 cultivation on media based on different nitrogen sources, statistical analyses were performed. Since the cultivation broth proved to be more effective against the examined test microorganism under the applied experimental conditions only results obtained for cultivation broth were further analysed and discussed. The results of two-way ANOVA analysis are given in Table 2 .

The results presented in Table 2 suggested that $p$-values for the analysed parameters and their interaction were much lower than 0.05 , which indicated that varied organic and inorganic nitrogen sources as well as their combinations have a statistically significant effect on the production of antibacterial compounds effecttive against $X$. campestris ATCC 13951 by $B$. subtilis ATCC 6633. According to the results presented in Table 2 it can be noted that inorganic nitrogen had the highest influence, while organic nitrogen 
had the lowest effect on the production of bioagents that can be used in crucifers black rot control.

The results of statistical analysis of effect of different organic and inorganic nitrogen sources on the inhibition zone diameter against $X$. campestris ATCC 13951 are presented graphically in Figures 2 and 3 , respectively. From graphically represented results (Figure 2) it can be observed that the highest inhibition zone diameters were formed when media without addition of organic nitrogen source were used. Somewhat lower values of inhibition zone diameter were achieved when yeast extract, soybean flour and peptone were added in cultivation media.

These observations are in accordance with the results from literature data which indicate that antagonist bacteria such as $B$. subtilis can grow and produce numerous bioactive substances on media with various nitrogen sources, whilst maintaining the efficacy of the biocontrol agent (Peighamy-Ashnaei et al., 2007).

\section{Table 1.}

Analysis of variance (One-Way ANOVA) of the effect of different sample preparation method on the antibacterial activity against Xanthomonas campestris ATCC 13951

\begin{tabular}{lccccc}
\hline Effect & SS & DF & MS & F-value & $p$-value \\
\hline Sample preparation method & 950.04 & 1 & 950.04 & 75.952 & $<0.000001$ \\
Error & 1175.79 & 94 & 12.51 & - & - \\
\hline
\end{tabular}

SS - sum of squares; DF - degrees of freedom; MS - mean square

\section{Table 2.}

Analysis of variance (Two-Way ANOVA) of the effect of different nitrogen sources on the production of antibacterial compounds effective against Xanthomonas campestris ATCC 13951 by Bacillus subtilis ATCC 6633

\begin{tabular}{lrrrrc}
\hline Effect & \multicolumn{1}{c}{ SS } & DF & \multicolumn{1}{c}{ MS } & F-value & $\boldsymbol{p}$-value \\
\hline Organic nitrogen & 34.06 & 3 & 11.35 & 5.142 & 0.005145 \\
Inorganic nitrogen & 328.56 & 3 & 109.52 & 49.594 & $<0.000001$ \\
Organic and inorganic nitrogen & 166.02 & 9 & 18.45 & 8.353 & 0.000003 \\
Error & 70.67 & 32 & 2.21 & - & - \\
\hline
\end{tabular}

SS - sum of squares; $D F-$ degrees of freedom; $M S$ - mean square

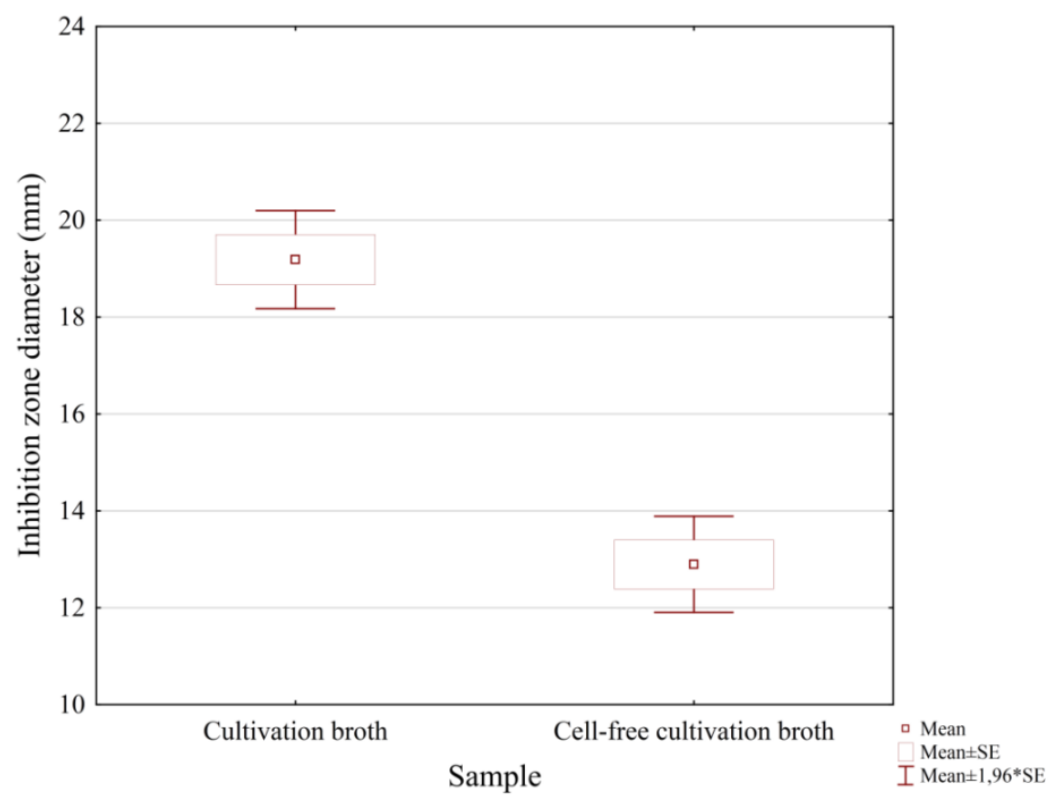

Figure 1. Effect of different sample preparation method on the antibacterial activity against Xanthomonas campestris ATCC 13951 
Ida E. Zahović et al., Production of biobactericides for crucifers black rot control: effect of nitrogen sources,

Food and Feed Research, 47 (1), 13-22, 2020

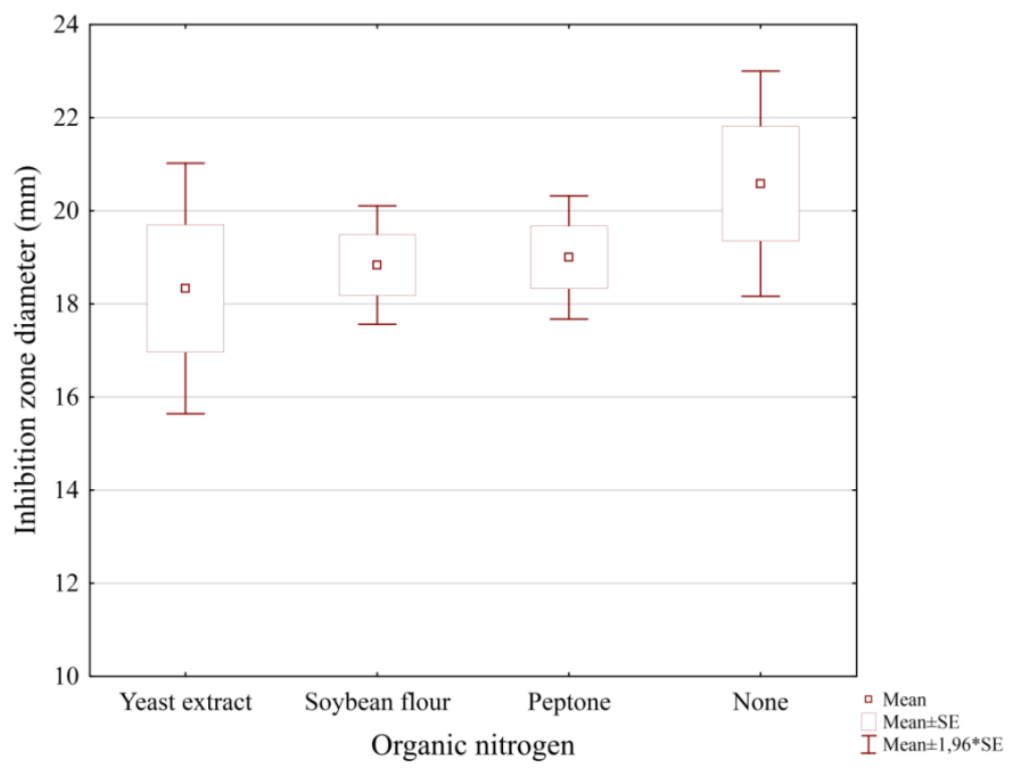

Figure 2. Effect of different organic nitrogen sources on the production of antibacterial compounds effective against Xanthomonas campestris ATCC 13951 by Bacillus subtilis ATCC 66331

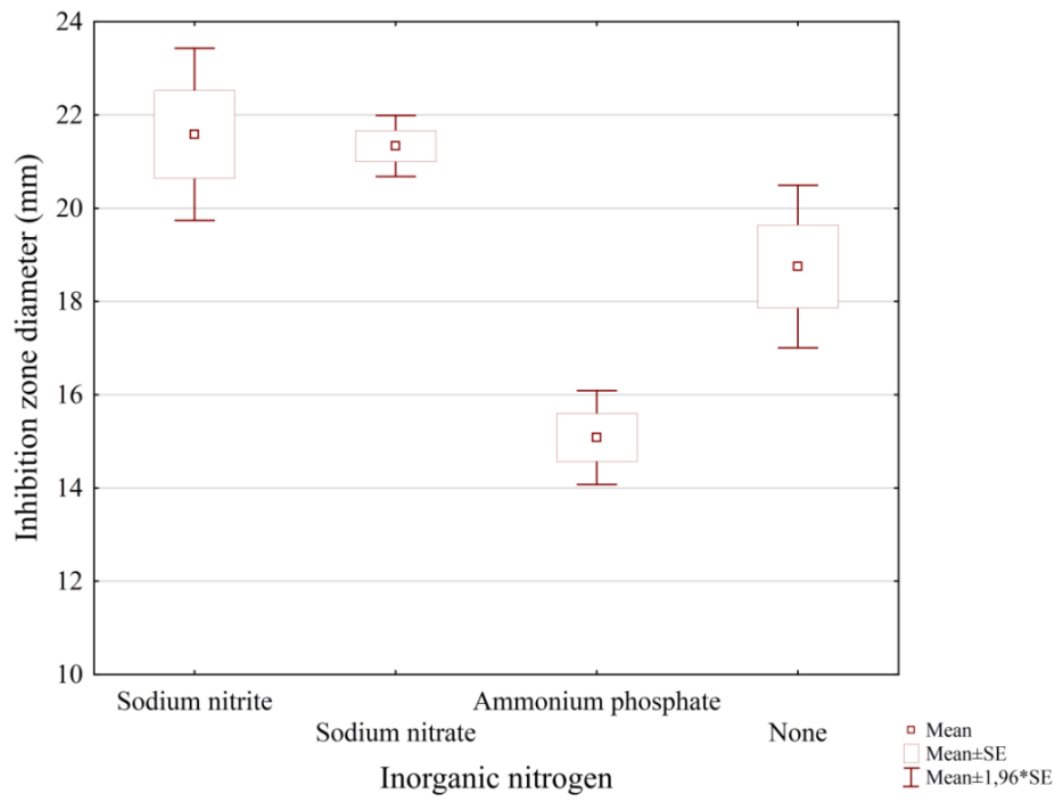

Figure 3. Effect of different inorganic nitrogen sources on the production of antibacterial compounds effective against Xanthomonas campestris ATCC 13951 by Bacillus subtillis ATCC 66331

The results presented in Figure 3 show that the highest inhibition zone diameters were achieved when sodium nitrite was used as inorganic nitrogen source. This result is following the results from previous research (Rončević et al., 2014) in which the maximum inhibition zone of about 26 $\mathrm{mm}$ in diameter, was achieved using this sodium salt as a nitrogen source. According to the obtained results, it can be noted that there was no statistically significant difference in the obtained values of inhibition zone diameters when using sodium nitrite and sodium nitrate as an inorganic nitrogen source in cultivation media $(p=0.280151)$. To define the combination of organic and inorganic nitrogen source in the medium for biobactericides production by Bacillus subtilis ATCC 66331, the values for inhibition zone diameter against Xanthomonas campestris ATCC 13951 was analysed using Duncan's multiple range test. Obtained data are presented in Table 3. 
Ida E. Zahović et al., Production of biobactericides for crucifers black rot control: effect of nitrogen sources,

Food and Feed Research, 47 (1), 13-22, 2020

Table 3.

Duncan's multiple range test: mean \pm standard deviation for inhibition zone diameter against Xanthomonas campestris ATCC 13951 formed by media with different organic and inorganic nitrogen sources

\begin{tabular}{ccc}
\hline Organic nitrogen & Inorganic nitrogen & Inhibition zone diameter $(\mathbf{m m})$ \\
\hline Yeast extract & $\left(\mathrm{NH}_{4}\right)_{2} \mathrm{HPO}_{4}$ & $13.33 \pm 2.08^{\mathrm{a}}$ \\
None & $\left(\mathrm{NH}_{4}\right)_{2} \mathrm{HPO}_{4}$ & $14.67 \pm 1.53^{\mathrm{a}, \mathrm{b}}$ \\
Yeast extract & $\mathrm{None}$ & $14.67 \pm 1.15^{\mathrm{a}, \mathrm{b}}$ \\
Peptone & $\left(\mathrm{NH}_{4}\right)_{2} \mathrm{HPO}_{4}$ & $15.67 \pm 1.15^{\mathrm{a}, \mathrm{b}}$ \\
Soybean flour & $\left(\mathrm{NH}_{4}\right)_{2} \mathrm{HPO}_{4}$ & $16.67 \pm 0.58^{\mathrm{b}, \mathrm{c}}$ \\
Soybean flour & $\mathrm{NaNO}_{2}$ & $18.33 \pm 2.08^{\mathrm{c}, \mathrm{d}}$ \\
Soybean flour & $\mathrm{None}^{\mathrm{c}}$ & $18.67 \pm 1.15^{\mathrm{c}, \mathrm{d}}$ \\
Peptone & $\mathrm{NaNO}_{2}$ & $19.33 \pm 1.53^{\mathrm{c}, \mathrm{d}, \mathrm{e}}$ \\
Peptone & $\mathrm{None}^{\mathrm{d}}$ & $20.00 \pm 1.00^{\mathrm{d}, \mathrm{e}}$ \\
None & $\mathrm{NaNO}_{3}$ & $20.67 \pm 1.15^{\mathrm{d}, \mathrm{e}, \mathrm{f}}$ \\
Peptone & $\mathrm{NaNO}_{3}$ & $21.00 \pm 1.00^{\mathrm{d}, \mathrm{e}, \mathrm{f}}$ \\
Soybean flour & $\mathrm{NaNO}_{3}$ & $21.67 \pm 1.53^{\mathrm{e}, \mathrm{f}}$ \\
None & $\mathrm{None}^{\mathrm{e}}$ & $21.67 \pm 2.89^{\mathrm{e}, \mathrm{f}}$ \\
Yeast extract & $\mathrm{NaNO}_{3}$ & $22.00 \pm 1.00^{\mathrm{e}, \mathrm{f}}$ \\
Yeast extract & $\mathrm{NaNO}_{2}$ & $23.33 \pm 1.53^{\mathrm{f}, \mathrm{g}}$ \\
None & $\mathrm{NaNO}_{2}$ & $25.33 \pm 0.58^{\mathrm{g}}$ \\
\hline Values in the same column marked with the same letter are not significantly different at $\alpha=0.05$
\end{tabular}

Table 4.

Inhibition zone diameter against Xanthomonas strains isolated from cabbage, kale and cauliflower formed by media with optimal combination of organic and inorganic nitrogen sources

\begin{tabular}{ccccc}
\hline \multirow{2}{*}{$\begin{array}{c}\text { Xanthomonas campestris } \\
\text { isolate }\end{array}$} & \multicolumn{4}{c}{ Inhibition zone diameter (mm) } \\
\cline { 2 - 5 } & Run 1 & Run 2 & Run 3 & Average \pm St. dev. \\
\hline Cabbage & 26 & 26 & 25 & $25.67 \pm 0.58$ \\
Kale & 32 & 34 & 34 & $33.33 \pm 1.15$ \\
Cauliflower & 31 & 34 & 32 & $32.33 \pm 1.53$ \\
\hline
\end{tabular}

From the results of Duncan's multiple range test presented in Table 3 , it can be seen that the highest inhibition zone diameter of $25.33 \pm 0.58 \mathrm{~mm}$ was accomplished when the cultivation of $B$. subtillis ATCC 6633 was performed on the medium containing none of organic nitrogen source and $\mathrm{NaNO}_{2}$ as an inorganic nitrogen source. As it can be noted, this result is at the same level of significance as results obtained when yeast extract was used as an organic and $\mathrm{NaNO}_{2}$ as an inorganic nitrogen source in cultivation medium $(p=0.109223)$. Although there is no statistically significant difference in the results discussed above, from an economic point of view it is more suitable to use cultivation medium without the addition of an organic nitrogen source, especially since it is a yeast extract which is an expensive component of the medium (Liu et al., 2019). All this is more pronounced when it comes to industrial scale-up of biotechnological production processes.

By the aforementioned results which are related to optimal organic and inorganic nitrogen sources in cultivation media, the efficacy of antibacterial metabolites production using $B$. subtillis ATCC 6633 was tested on Xanthomonas strains isolated from cabbage, kale and cauliflower. The obtained results are presented in Table 4.

As can be seen from the results displayed in Table 4, it can be noted that the highest inhibition zone diameter of $33.33 \pm 1.15 \mathrm{~mm}$ was detected against Xanthomonas strain isolated from kale. Besides, the results suggest that $B$. subtilis ATCC 6633 had higher antibacterial activity against isolated Xanthomonas strains $(25.67 \pm 0.58$ $\mathrm{mm}, 32.33 \pm 1.53 \mathrm{~mm}, 33.33 \pm 1.15 \mathrm{~mm}$ ) 
comparing to the reference strain $(25.33 \pm 0.58 \mathrm{~mm})$.

\section{CONCLUSIONS}

In this research, the evaluation of antibacterial metabolites biosynthesis by Bacillus subtilis ATCC 6633 effective against black rot pathogens and the definition of optimal nitrogen sources combination in the glycerol-based medium was performed. The obtained results confirmed that using organic and inorganic nitrogen sources as well as their combination had a statistically significant effect on the biobactericides production in applied conditions. The maximal inhibition zone diameter against the test microorganism was accomplished when cultivation of B. subtilis ATCC 6633 was performed on organic nitrogen-free medium with $\mathrm{NaNO}_{2}$ as the inorganic nitrogen source. The experimental data also suggested that the high inhibition zone diameters against isolated $X$. campestris strains were achieved when cultivation broth with live bacterial cells was tested, which indicated that antibacterial activity of applied producing strain is associated with the cells. Results from this study can be a suitable background for future investigations and optimization of the economically justified production of antibacterial compounds effecttive against $X$. campestris strains by $B$. subtilis ATCC 6633 at an industrial scale.

\section{ACKNOWLEDGEMENTS}

This study is part of the project (451-0368/2020-14/ 200134) funded by the Ministry of Education, Science and Technological Development of the Republic of Serbia.

\section{REFERENCES}

1. Bauer, A.W., Kirby, W.M.M., Sherris, J.C., Turck, M. (1966). Antibiotic susceptibility testing by a standardized single discmethod. American Journal of Clinical Pathology, 45 (4), 493-496.

2. Caulier, S., Nannan, C., Gillis, A., Licciardi, F., Bragard, C., Mahillon, J. (2019). Overview of the antimicrobial compounds produced by members of the Bacillus subtilis group. Frontiers in Microbiology, 10, 302.

3. Da Silva R.S., de Oliveira M.M.G., de Melo J.O., Blank, A.F., Corrêa, C.B., Scher, R., Fernandes, R.P.M. (2019). Antimicrobial activity of Lippiagracilis essential oils on the plant pathogen Xanthomonas campestris pv. campestris and their effect on membrane integrity. Pesticide Biochemistry and Physiology, 160, 40-48.

4. Davis, D.A., Lynch, H.C., Varley, J. (1999). The production of Surfactin in batch culture by Bacillus subtilis ATCC 21332 is strongly influenced by the conditions of nitrogen metabolism. Enzyme and Microbial Technology, 25 (3-5), 322-329.

5. De Britto, A.J., Gracelin, D.H.S., Sebastian, S.R. (2011). Antibacterial activity of a few medicinal plants against Xanthomonas campestris and Aeromonashydrophila. Journal of Biopesticides, 4 (1), $57-60$.

6. De Paula Kuyat Mates, A., de Carvalho Pontes, N., de Almeida Halfeld-Vieira, B. (2019). Bacillus velezensis GF267 as a multi-site antagonist for the control of tomato bacterial spot. Biological Control, $137,104013$.

7. El-Hendawy, H.H., Osman, M.E., Sorour, N.M. (2005). Biological control of bacterial spot of tomato caused by Xanthomonas campestris pv. vesicatoria by Rahnella aquatilis. Microbiological Research, 160 (4), 343-352.

8. Fernandes, P.A.V., de Arrud, I.R., dos Santos, A. F.A.B., de Araújo, A.A., Maior, A.M.S., Ximenes, E.A. (2007). Antimicrobial activity of surfactants produced by Bacillus subtilis R14 against multidrugresistant bacteria. Brazilian Journal of Microbiology, 38 (4),704-709.

9. Fira, D., Dimkić, I., Berić, T., Lozo, J., Stanković, S. (2018). Biological control of plant pathogens by Bacillus species. Journal of Biotechnology, 285, 4455.

10. Grahovac, J., Grahovac, M., Dodić, J., Bajić, B. Balaž, J. (2014). Optimization of cultivation medium for enhanced production of antifungal metabolites by Streptomyces hygroscopicus. Crop Protection, 65, 143-152.

11. Huang, T.C., Chang, M.C. (1975). Studies on xanthobacidin, a new antibiotic from Bacillus subtilis active against Xanthomonas. Botanical Bulletin of Academia Sinica, 16, 137-148.

12. Issazadeh, K., Rad, S.K., Zarrabi, S., Rahimibashar, M.R. (2012). Antagonism of Bacillus species against Xanthomonas campestris pv. campestris and Pectobacterium carotovorum subsp. Carotovorum. African Journal of Microbiology Research, 6 (7), 1615-1620.

13. Khan, A.A.H., Naseem, Rupa, L., Prathibha, B. (2011). Screening and potency evaluation of antifungal from soil isolates of Bacillus subtilis on selected fungi. Advanced Biotechnology, 10 (7), 3537.

14. Larrea-Sarmiento, A., Dhakal, U., Boluk, G., Fatdal, L., Alvarez, A., Strayer-Scherer, A., Paret, M., Jones, J., Jenkins, D., Arif, M. (2018). Development of a genome-informed loop-mediated isothermal amplification assay for rapid and specific detection of Xanthomonas euvesicatoria. Scientific Reports, 8 (1), 14298.

15. Leelasuphakul, W., Hemmanee, P., Chuenchitt, S. (2008). Growth inhibitory properties of Bacillus subtilis strains and their metabolites against the green mold pathogen (Penicillium digitatum Sacc.) 
of citrus fruit. Postharvest Biology and Technology, 48 (1), 113-121.

16. Liu, T., Bessembayeva, L., Chen, J., Wei, L., Hua, Q. (2019). Development of an economical fermentation platform for enhanced ansamitocin P-3 production in Actinosyn nemapretiosum. Bioresources and Bioprocessing, 6 (1), 1.

17. Luna, C.L.R., Mariano, L.R., Souto-Maior, A.M. (2002). Production of a biocontrol agent for crucifers black rot disease. Brazilian Journal of Chemical Engineering, 19 (2), 133 - 140.

18. Mansfield, J., Genin, S., Magori, S., Citovsky, V., Sriariyanum, M., Ronald, P., Dow, M., Verdier, V., Beer, S. V., Machado, M.A., Toth, I., Salmond, G., and Foster, G.D. (2012). Top 10 plant pathogenic bacteria in molecular plant pathology: top 10 plant pathogenic bacteria. Molecular Plant Pathology, 13 , 614-629.

19. Meneses, E.A., Durango, D.L., García, C.M. (2009). Antifungal activity against postharvest fungi by extracts from Colombian propolis. Química Nova, 32 (8), 2011-2017.

20. Monteiro, L., de Lima Ramos Mariano, R., Souto-Maior, A.M. (2005). Antagonism of Bacillus spp. against Xanthomonas campestris pv. Campestris. Brazilian Archives of Biology and Technology, 48 (1), 23-29.

21. Peighamy-Ashnaei, S., Sharifi-Tehrani, A., Ahmadzadeh, M., Behboudi, K. (2007). Effect of carbon and nitrogen sources on growth and biological efficacy of Pseudomonas fluorescens and Bacillus subtilis against Rhizoctonia solani, the causal agent of bean damping-off. Communications in Agricultural and Applied Biological Sciences, 72 (4), 951956.

22. Radovanović, N., Milutinović, M., Mihajlovski, K., Jović, J., Nastasijević, B., Rajilić-Stojanović, M., Dimitrijević-Branković, S. (2018). Biocontrol and plant stimulating potential of novel strain Bacillus sp. PPM3 isolated from marine sediment. Microbial Pathogenesis, 120, 71-78.

23. Rončević, Z., Grahovac, J., Vučurović, D.,
Dodić, S., Bajić, B., Tadijan, I., Dodić, J. (2014). Optimization of medium composition for the production of compounds effective against Xanthomonas campestris by Bacillus subtilis. Acta Periodica Technologica,45, 247-258.

24. Rončević, Z., Zahović, I., Pajčin, I., Grahovac, M., Dodić, S., Grahovac, J., Dodić, J. (2019). Effect of carbon sources on xanthan production by Xanthomonas spp. isolated from pepper leaves. Food and Feed Research, 46 (1), 11-21.

25. Salerno, C.M., Sagardoy, M.A. (2003). Short communication: Antagonistic activity by Bacillus subtilis against Xanthomonas campestris pv. glycines under controlled conditions. Spanish Journal of Agricultural Research, 1, 55-58.

26. Suárez-Estrella, F., Arcos-Nievas, M.A., López, M.J., Vargas-García, M.C., Moreno, J. (2013). Biological control of plant pathogens by microorganisms isolated from agro-industrial composts. Biological Control, 67(3), 509-515.

27. Tabbene, O., Slimene, I.B., Djebali, K., Mangoni, M.L., Urdaci, M.C. (2009). Optimization of medium composition for the production of antimicrobial activity by Bacillus subtilis B38. Biotechnology Progress, 25 (5), 1267-1274.

28. Taylor, J.D., Conway, J., Roberts S.J., Astley, D., Vicente, J.G. (2002). Sources and origin of resistance to Xanthomonas campestris pv. campestris in Brassica genomes. Phytopathology, 92 (1), 105-111.

29. Vorhölter, F.-J., Thias, T., Meyer, F., Bekel , T., Kaiser, O., Pühler, A., Niehaus, K. (2003). Comparison of two Xanthomonas campestris pathovar campestris genomes revealed differences in their gene composition. Journal of Biotechnology, 106 (23), 193-202.

30. Wise, C., Novitsky, L., Tsopmo, A., Avis, T.J. (2012). Production and antimicrobial activity of $3-$ hydroxypropionaldehyde from Bacillus subtilis strain CU12. Journal of Chemical Ecology, 38 (12), 15211527. 
Ida E. Zahović et al., Production of biobactericides for crucifers black rot control: effect of nitrogen sources,

Food and Feed Research, 47 (1), 13-22, 2020

\section{ПРОИЗВОДЊА БИОБАКТЕРИЦИДА ЗА КОНТРОЛУ ЦРНЕ ТРУЛЕЖИ КУПУСЊАЧА: УТИЦАЈ ИЗВОРА АЗОТА}

Ида Е. Заховић*, Зорана 3. Рончевић, Јована Ј. Ђуран, Ивана Ж. Митровић,Јована А. Граховац, Синиша Н. Додић

Универзитет у НовомСаду, Технолошки факултет Нови Сад, 21000 Нови Сад, Булевар цара Лазара бр. 1, Србија

Сажетак: Циљ овог истраживања био је испитивање утицаја варијације органских (екстракт квасца, сојино брашно и пептон) и неорганских извора азота $\left(\mathrm{NaNO}_{2}, \mathrm{KNO}_{3}\right.$ и $\left.\left(\mathrm{NH}_{4}\right)_{2} \mathrm{HPO}_{4}\right)$ у медијуму за производњу биобактерицида применом Bacillus subtilis ATCC 6633. Антибактеријска активност против референтног соја Xanthomonas campestris ATCC 13951 и сојева Xanthomonas изолованих са листова купуса, кеља и карфиола утврђена је in vitro дискдифузионом методом. Статистичка анализа показала је да и органски и неоргански извори азота имају статистички значајан утицај на производњу биобактерицида у примењеним експерименталним условима при чему је утицај неорганског азота израженији. Резултати Данкановог теста сугеришу да је антимикробно деловање највише изражено у медијумима са и безорганског извора азота, а који као неоргански извор садрже $\mathrm{NaNO}_{2}$. Добијени резултати представљају погодну основу за даље унапређење производње биобактерицида применом референтног соја $B$. subtilis.

Кључне речи: производња биобактерицида, Bacillus subtilis, извор азота, црна трулеж, Xanthomonas campestris

Received: 23 December 2019

Received in revised form: 19 February 2020

Accepted: 14 May 2020 